\title{
Performance of Family and Non-family Firms with Self-Selection: Evidence from Dubai
}

\author{
Belaid Rettab ${ }^{1}$, Azzeddine Azzam ${ }^{1,2,3}$ \\ ${ }^{1}$ Dubai Chamber of Commerce \& Industry, Dubai, UAE \\ ${ }^{2}$ University of Dubai, Dubai, UAE \\ ${ }^{3}$ University of Nebraska-Lincoln, Lincoln, Nebraska, USA \\ E-mail: belaid.rettab@dubaichamber.ae \\ Received April 24, 2011; revised June 20, 2011; accepted June 30, 2011
}

\begin{abstract}
This paper contributes to the literature on comparative performance of family and non-family businesses by accounting for self-selection and by comparing performance within and across sectors. Using an extensive data set of Dubai businesses in the four different major sectors in the Dubai economy (construction, manufacturing, services, and trading); we find that the sector matters. Family businesses outperform nonfamily businesses in trading, followed by construction as a far second. Performance of family businesses is weakest in manufacturing and services, only in trading did family businesses outperform nonfamily exporting businesses in other sectors. Reasons for that are discussed and policy implications are drawn. We also find strong evidence of self-selection bias.
\end{abstract}

Keywords: Business Comparative Performance, Family Businesses, Self-Selection, Sector Performance, Dubai Enterprises

\section{Introduction}

In their overview of family business performance, Jackiewicz and Klein (2005) [1] report that of the 41 studies that compared family to nonfamily businesses, 25 find the former outperform the latter, 5 find the opposite, and 11 find no significant difference between the two types of firms. Dyer (2006) [2] argues that such differences in results are not surprising given the differences in approaches and definitions of family enterprises (see also [3-7]).

What is surprising, however, is that, as far as we know, none of the studies controlled for self-selection bias [8] and most do not assess differences in performance within and across industries. If selection bias is present, the observed differences in firm performance are attributed to business type when they may be due to differences between the entrepreneurs who chose between the two types of business structures. Similarly, if a business' amenability to family versus nonfamily management hinges on the type of industry, it is crucial to have industry an additional contextual variable.

In this paper we use an extensive data set of Dubai businesses to test for differences in family versus non- family firms within and across the four major sectors in the Dubai economy (construction, manufacturing, services, and trading). Dubai is a particularly interesting and representative case study of the Gulf region, where, until the recent financial crisis, economic growth has been phenomenal and little is known about the relative performance of family businesses and thereby their relative contribution to such growth. Family businesses comprise most of the enterprises in the Gulf region [9]. They account for over $90 \%$ of all commercial activities in the Gulf region, compared to rates ranging from $65 \%$ to $80 \%$ in other regions of the world.

The remainder of the article is organized as follows. The next section reviews and discusses the literature on comparative performance of family and nonfamily firms. Section 3 defines a family business in general, and Section 4 develops a working definition for a family business in Dubai. Section 5 presents the data, method, and results. Section 6 summarizes and concludes.

\section{Family versus Non-family Performance}

Casting comparative performance of firms in terms of family versus non-family businesses is a useful approach 
to capturing the influence of business structure on business performance. One particularly important element of structure, discussed extensively in the literature, is the degree of ownership and management control [2,10-13]).

It is generally accepted that concentration of control can bring about economic entrenchment and misallocation of resources [14]. Misallocation is attributed to the well-known principle-agent problem but also to the principal-principal conflict emphasizing the problem of minority shareholders $[15,16])$. The latter conflict is commonly present in emerging economies with institutions that encourage control and tolerate bad corporate governance. In this context, does high concentration of control, as exhibited by a family enterprise, affect firm performance? And what is the role of the supporting institutions operating in the background?

On one hand, institutions are found to significantly determine business performance [17-20]. On the other hand, in the absence of sound institutions and regulatory framework, is ownership and control able to provide a less enforced, but equally potent, internal regulatory environment for business? In China for example, it is reported that family businesses provide alternative framework for businesses to "reduce risk in uncertain, complex and potentially hostile environments" [21].

Furthermore, the degree of concentration of ownership and control is motivated by business strategies, strategies to manage risks stemming from surrounding institutions. Minority shareholders in publicly owned companies have, in general, highly diversified investment portfolios and are therefore considered more likely to accept potentially risky ventures in return for lucrative earnings. Conversely, the owner of a family firm is likely to have a more concentrated investment portfolio, holding a high proportion of personal wealth within the own firm [11,22-24]). Consequently, does this excessive cautious behaviour hinder family firm performance [12,22], and results in sub-optimal capital asset structure and performance?

Some researchers [3] suggest that due to corporate governance issues, such as the lack of transparency and accountability, family enterprises remain small and, therefore, have less access to capital. However, the evidence is inconclusive across samples. Jorissen et al. (2005) [25] report that once demographic differences are controlled for, family firms face more financing problems than non-family firms with regards to long- term financing $[4,23]$.

In this connection, Anderson and Reeb (2003) [4] contend that family owners are predominantly concerned with "stability and capital preservation" rather than firm growth, performance and size. However, if stability is used as an indicator of firm performance, Lee (2006) [26] would agree and Suehiro (2001) [27] would disagree that family firms are more stable in times of economic downturn than non-family enterprises.

What transpires from the previous discussion is that, because of the several characteristics of family versus nonfamily firms and the interaction between those characteristics, there is no clear a priori expectation that one type of firm should outperform the other. That expectation becomes less clear when considering contextual variables such as firm size and industry. Hence, relative performance of family versus non-family firms is an empirical question, and preponderance of evidence from different studies is what ultimately shapes the metaview of the superiority of one business over the other. Our empirical analysis for Dubai is a contribution to shaping that metaview. Our starting point is to discuss in the next section the different definitions for a family business used in the literature. After that we discuss our definition of what constitutes a family business in Dubai.

\section{Definition of a Family Business}

The assortment of family business attributes outlined in section 2 has led to an assortment of definitions of a family business in the literature. In their survey of family business literature, Chua et al. (1999) [28] found 21 different definitions.

Basically, family business attributes are related to one of three components: family, ownership, and management; and the definition of a family business depends on the overlap of the three. This is illustrated in the Venn diagram in Figure 1. The three components plus the four overlapping areas constitute seven possible connections, with each connection tied to some degree of influence. Individuals with only one connection to the business would lie in 1,2 , or 3 , and those with more than one connection would lie in any of the other intersections. For example, intersections 4, 5, and 7 identify family members who are directly involved in the business management and its ownership. Intersections 2, 3, and 6 include managers, employees and possible co-owners from outside the family.

Several examples from the literature will serve to illustrate how different authors in different contexts have devised different definitions based on the overlapping components shown in the Venn diagram. Westhead and Cowling (1997) [6] suggested the following 7 definitions for a family business:

1) The enterprise is perceived by the chief executive, managing director, or chairman to be a family business.

2) More than $50 \%$ of ordinary voting shares are owned by members of the largest single-family group related by blood or marriage.

3) 1 and 2

4) 3 and one or more of the management team is 


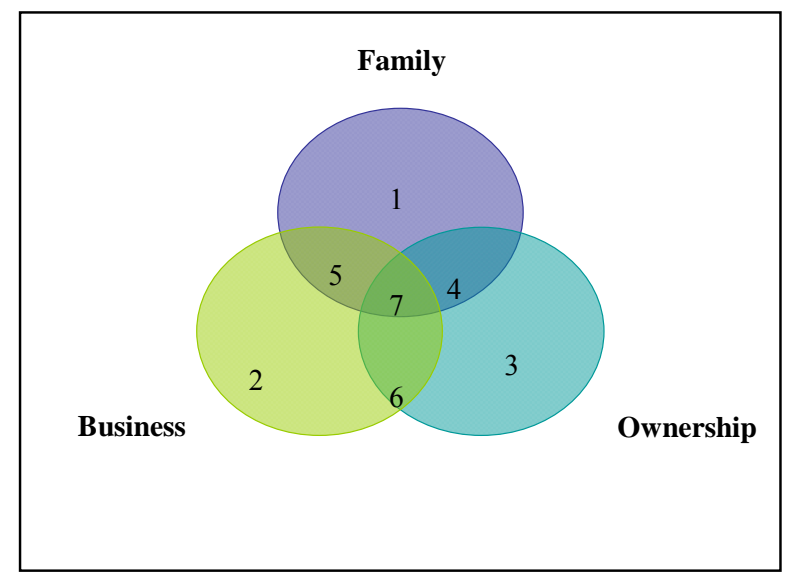

Figure 1. Overlapping Components of a Family Business. Source: Gersick et al., (1997) [29].

drawn from the largest family group that owns the business

5) 3 and $51 \%$ or more of the management team is drawn from the largest family group that owns the business

6) 4 and the enterprise is owned by second-generation or family members

7) 5 and the enterprise is owned by second-generation or family members

\section{Definition of a Family Business in the Context of Dubai}

The preceding conceptual framework and applications not only require information on family membership, degree of ownership and management by family members; they also require establishing a cut-off point at which the degree of influence is significant enough to designate a business as a family business. Unfortunately, that information is not available for Dubai

What is available is a categorization of family versus non-family businesses in Dubai devised by Rettab (2008) [30] (Table 1). The definition draws on UAE's company law which requires $51 \%$ ownership of a business by UAE nationals, and on labour law regulating employer-employee ${ }^{1}$ relationship.

According to Table 1, a business that is more than $50 \%$ owned and managed by UAE nationals is defined as a family business, while all other businesses are defined as non-family businesses. The underlying rationale is as follows.

A business that is fully owned by UAE nationals in almost all cases belongs to one single UAE national owner, regardless of the size of the business. Hence, all

${ }^{1}$ Residency visa of all expat employees is dependent on employment contracts. Once a contract is terminated, the employee must either leave the country or find another employer. The Law also applies to CEOs.
Table 1. Categories of UAE Owned Businesses in Dubai according to ownership, Management, and Number of Owners and Managers.

\begin{tabular}{|c|c|c|c|c|}
\hline $\begin{array}{l}\text { Defini- } \\
\text { tions }^{1}\end{array}$ & $\begin{array}{c}\text { Numbers of } \\
\text { Owners and } \\
\text { Managers }\end{array}$ & Ownership & Management & Category \\
\hline 3 & 1 & $100 \%$ Family & $100 \%$ Family & $\begin{array}{c}\text { One-Man Family } \\
\text { Business }\end{array}$ \\
\hline 2 & 2 & $>50 \%$ Family & $\begin{array}{c}100 \% \text { Family } \\
\text { or Shared }\end{array}$ & Family Business \\
\hline 4 & 2 & $>50 \%$ Family & $\begin{array}{c}100 \% \\
\text { Non-Family }\end{array}$ & $\begin{array}{c}\text { Non-Family } \\
\text { Business } \\
\text { (The Sponsorship } \\
\text { System) }\end{array}$ \\
\hline 1 & \multirow{4}{*}{3 or more } & $>50 \%$ Family & $\begin{array}{c}100 \% \text { Family } \\
\text { or Shared }\end{array}$ & $\begin{array}{c}1^{\text {st }} \text { Category } \\
\text { Family Business } \\
\text { Non-Family }\end{array}$ \\
\hline \multirow{3}{*}{5} & & $>50 \%$ Family & $\begin{array}{c}100 \% \\
\text { Non-Family }\end{array}$ & $\begin{array}{c}\text { Business } \\
\text { (The Sponsorship } \\
\text { System) }\end{array}$ \\
\hline & & $<50 \%$ Family & $\begin{array}{c}100 \% \text { Family } \\
\text { or Shared }\end{array}$ & $\begin{array}{c}\text { Non-Family } \\
\text { Business }\end{array}$ \\
\hline & & $<50 \%$ Family & $\begin{array}{c}100 \% \\
\text { Non-Family }\end{array}$ & $\begin{array}{c}\text { Non-Family } \\
\text { Business }\end{array}$ \\
\hline
\end{tabular}

${ }^{1}$ Numbers in column refer to the categories by Westhead and Cowling (1997) [6]. Source: Rettab (2008) [30].

fully UAE national owned businesses are family businesses.

Defining businesses with a share of foreign equity as non-family businesses is supported by the roles of the UAE partner in the day-to-day management of the business. There are three roles. One, in almost all small businesses (less than 10 workers) with foreign equity, the formal owner of the license is the so-called the UAE national sponsor or the silent partner. The partnership is a well established sponsorship system enforced by law. In this case, since the capital is wholly provided by the foreign partner(s) who attend to all activities and take all decisions related to the conduct of the business, the foreign partners are the actual owners and the managers in full control. The UAE partner does not actively participate in the day-to-day business management but sponsorship is just an arrangement to conform to the Federal Company Law. Therefore, small businesses with foreign equity are classified as nonfamily businesses.

Two, in medium-sized businesses (10 to 19 workers) with foreign equity, UAE nationals are more likely to be non-silent partners, but their presence in the firm is mostly for formality reasons and for facilitating access to local authorities and agencies, as well as monitoring local employees and local clientele. However, control and management remain in the hands of foreign partners.

Three, large businesses (20 employees or more) with foreign equity are formally organized and ownership of capital and liabilities of owners are stipulated in legal documents. However, in most such businesses, although the UAE partner is a member of the board of directors 
because of his/her share in capital investment, decision-makers are usually foreigners. Therefore, large businesses with foreign equity are also assumed to be non-family businesses.

\section{Data and Analysis}

The data set we extract information from to examine the comparative performance of family versus nonfamily businesses comes from the 2005 Dubai Chamber's membership database. The total number of members is 20,576; 10,597 are family businesses and 9979 are nonfamily businesses. Reported by each business are income, exports, number of owners, number of employees, paid-up capital, cohort (whether a business started operation before or after 1990), location (whether or not a business is located in the free zone), and the industry category to which a business belongs. The industry categories are manufacturing, construction, trading, and services.

Performance is represented by the following linear model:

$$
\begin{aligned}
Y_{n i j k}=\mu & +B_{i}+I_{j}+E_{k}+\alpha_{i j k} * O W N_{n i j k} \\
& +\beta_{i j k} * C A P_{n i j k}+\delta_{i j k} * E M P_{n i j k} \\
& +(B * I) i j+(B * E)_{j k}+(I * E)_{j k} \\
& +(B * I * E)_{i j k}+\gamma * S S+e_{n i j k}
\end{aligned}
$$

where $Y$ is income, $\mu$ is the intercept, $B$ is business type, $I$ is industry category, $E$ is export status, $O W N$ is the number of owners, $C A P$ is paid-up capital, EMP is number employees, and $S S$ is a measure of self-selection. The subscript nijk refers to nth firm, for $n=1, \ldots 20576$; in the ith business, where $i=1$ for a family business and $i=2$ for a nonfamily business; in the jth sector, where $j=1$ for manufacturing (MAN), $j=2$ for construction $(\mathrm{CON}), j=$ 3 for trading (TRD), and $j=5$ for services (SRV). The subscript $k$ is equal to 1 if the firm exports and 2 if it does not.

Although the choice of variables is ex-post, as it is dictated by what is available in the data set, the variables capture the essence, although imperfectly, of some determinants of family versus non-family firms outlined in Section 2. The number of owners is a proxy for agency costs, i.e., the larger the number of owners the higher the agency costs. Paid-up capital is a proxy for risk and extent of internal financing. The number of employees could, as has been assumed in past work, be an indicator of the size of the firm as well as agency costs. With a larger pool of employees, issues related to moral hazard take on crucial importance.

The variable $S S$ is the inverse mills ratio calculated from a Probit model as suggested by Heckman (1979) [8]. The ratio controls for selection. A positive (negative) $\gamma$ that is statistically different from zero indicates presence of selection bias that overstates (understates) the effect family business structure on performance. The bias is overstated (understated) if stronger (weaker) "business people" chose to run a family business. The error $e_{n i j k} \sim$ iid $N\left(0, \sigma^{2}{ }_{i j k}\right)$ accounts for the error structure which allows for heterogeneous variances by business type, industry, and export status.

The Probit model explains belonging to a family or a nonfamily business $\left(B_{i}\right)$ as a function of the number of owners (OWN), paid-up capital (CAP), number of employees (EMP), Location (LOC), industry category (I), and an indicator $(\mathrm{COH})$ which equals 1 if the business started before 1990 and zero after 1990. The period after 1990 represent the take-off growth period for Dubai. Results of the Probit model are presented in Table 2.

What transpires from the Probit results is that firms with more owners are less likely to organize as family businesses, as were firms who started business after 1990, a period which witnessed strong FDI inflow to Dubai. The rest of the variables all increase the likelihood of a firm organizing itself as a family business.

From the Probit results, we construct the mills ratio: $S S=\varphi(X, \gamma) / \Phi(X, \gamma)$, where $\varphi(X, \gamma)$ is the density function, $\Phi(X, \gamma)$ is the distribution function, and $\theta$ is the vector of parameter estimates from the Probit model reported in Table 2.

Before estimating the linear statistical model of performance (Equation (1)), we conducted a preliminary check of the distribution of the regressors through histograms. The check revealed that the regressors are highly skewed, with the largest values of some regressors often being the smallest values. A rule of thumb is that if the largest value is more than three times larger than the smallest value, a log transformation of the regressors is needed, mitigating the problem of extreme outliers [31].

The performance equation was estimated using the SAS Proc Mixed routine [32] by first transforming the variables $\mathrm{Y}$, OWNERS, CAP, and EMP into logarithms and incorporating a different residual variance $\sigma^{2}{ }_{i j k}$ for each business $(i=1,2)$ by industry $(j=1,2,3,4)$ by export status combination $(k=1,2)$. Estimates of the

Table 2. Parameter Estimates of the Probit Model

\begin{tabular}{cccccc}
\hline Parameter & & Estimate & Standard Error & Chi-Square & Pr $>\chi^{2}$ \\
\hline Intercept & 0.694 & 0.0897 & 59.96 & $<.0001$ \\
OWN & -0.650 & 0.0072 & 8133.68 & $<.0001$ \\
CAP & 0.067 & 0.0110 & 38.21 & $<.0001$ \\
EMP & 0.0005 & 0.0001 & 85.04 & $<.0001$ \\
LOC & DUBAI & 1.172 & 0.0856 & 187.50 & $<.0001$ \\
I & CON & 0.154 & 0.0393 & 15.53 & $<.0001$ \\
I & MFG & 0.454 & 0.0475 & 91.30 & $<.0001$ \\
I & SRV & 0.675 & 0.0325 & 431.53 & $<.0001$ \\
COH & AFTER & -0.380 & 0.0229 & 274.74 & $<.0001$ \\
\hline
\end{tabular}


16 residual variances were obtained by performing a separate regression for each one of the 16 combinations. The solution for fixed effects yielded 93 parameter estimates, including the intercept.

The first hypothesis of interest is self-selection bias. The coefficient $\gamma$ for the variable controlling for selection is 0.239 and a standard error 0.049 , indicating (statistically) strong presence of self-selection bias that tends to overstate the effect of family business structure on performance. The implication is that analysis for comparative performance of family and nonfamily businesses in the Dubai case should account for self-selection bias.

The next hypotheses of interest are those related to the statistical importance of the fixed effects, the covariates, and interactions thereof. Results are reported in Table 3.

Individually, the fixed effects $B, I$ and $E$ are highly significant and so are the covariates $O W N, E M P$, and $C A P$. The interactions are all highly significant with three exceptions: business type by exports status $\left(B^{*} E\right)$, industry type by export status $\left(I^{*} E\right)$, and business type by industry by numbers of owners $\left(O W N^{*} B^{*} I\right)$.

Next we take a look at the comparative performance of family business vis-à-vis nonfamily businesses by industry and by export status. Table 4 compares mean performance of family and nonfamily businesses in the construction sector. The rows highlighted in gray indicate instances of superior performance of family businesses. The first highlighted row in gray is read as follows: a family business in the construction sector that does not export outperforms a nonfamily business in construction that does not export. The second highlighted row indicates that a family business in construction that does not export outperforms a nonfamily business in manufacturing that does not export. The rest of the rows can be read in a similar manner.

Results for construction can be summarized as follows. Family businesses in construction outperformed nonfamily businesses in $44 \%$ of all cases, outperformed nonfamily businesses in the construction business only when nonfamily businesses are not exporters, and in no other instance did family businesses outperform nonfamily businesses who export.

Results for manufacturing are in Table 5. It appears that family businesses in manufacturing outperform nonfamily businesses only in $25 \%$ of the cases, outperformed nonfamily businesses in manufacturing only when nonfamily businesses in manufacturing are not exporters, and, as in construction; in no other instance did they outperform nonfamily businesses who export.

In the services industry (Table 6), family businesses outperformed nonfamily business only in $25 \%$ of the cases, did not outperform nonfamily businesses in services only when the family business exports and the nonfamily business does not, and in no other instance did they outperform nonfamily businesses in services who export.

The outcome for the trading sector is radically different (Table 7). Family businesses outperform nonfamily business in $7 \%$ of the cases. Trading family businesses who do not export outperform only nonfamily businesses who do not export. However, trading family businesses

Table 3. Type 3 Tests of Fixed Effects.

\begin{tabular}{ccccc}
\hline Effect & Num DF & Den DF & F Value & Pr $>$ F \\
\hline B & 1 & 2114 & 17.26 & $<.0001$ \\
I & 3 & 1677 & 8.99 & $<.0001$ \\
E & 1 & 182 & 107.93 & $<.0001$ \\
B*I & 3 & 1659 & 10.82 & $<.0001$ \\
B*E & 1 & 182 & 0.01 & 0.9098 \\
I*E & 3 & 172 & 0.15 & 0.9300 \\
B*I*E & 3 & 172 & 3.12 & 0.0275 \\
OWN & 1 & 6011 & 63.12 & $<.0001$ \\
CAP & 1 & 1824 & 3210.36 & $<.0001$ \\
EMP & 1 & 1033 & 758.01 & $<.0001$ \\
OWN*B & 1 & 2776 & 13.24 & 0.0003 \\
CAP*B & 1 & 1819 & 11.41 & 0.0007 \\
EMP*B & 1 & 1001 & 20.76 & $<.0001$ \\
OWN*I & 3 & 2275 & 10.64 & $<.0001$ \\
CAP*I & 3 & 1444 & 12.54 & $<.0001$ \\
EMP*I & 3 & 1349 & 12.05 & $<.0001$ \\
OWN*B*I & 3 & 2290 & 1.49 & 0.2153 \\
CAP*B*I & 3 & 1435 & 17.29 & $<.0001$ \\
EMP*B*I & 3 & 1342 & 6.47 & 0.0002 \\
\hline
\end{tabular}

Table 4. Comparative performance of family businesses in construction.

\begin{tabular}{|c|c|c|c|c|c|c|c|c|c|c|}
\hline $\mathrm{B}$ & I & $\mathrm{E}$ & $\mathrm{B}$ & $\mathrm{I}$ & $\mathrm{E}$ & Estimate & Standard Error & DF & t Value & $\operatorname{Pr}>|t|$ \\
\hline FAM & $\mathrm{CON}$ & $\mathrm{NO}$ & NFAM & $\mathrm{CON}$ & $\mathrm{NO}$ & 0.2677 & 0.1000 & 1135 & 2.68 & 0.0076 \\
\hline FAM & $\mathrm{CON}$ & $\mathrm{NO}$ & NFAM & $\mathrm{CON}$ & YES & -0.02721 & 0.1483 & 584 & -0.18 & 0.8545 \\
\hline FAM & $\mathrm{CON}$ & $\mathrm{NO}$ & NFAM & MFG & $\mathrm{NO}$ & 0.5384 & 0.1152 & 1158 & 4.67 & $<.0001$ \\
\hline FAM & $\mathrm{CON}$ & $\mathrm{NO}$ & NFAM & SRV & NO & 0.2963 & 0.08637 & 794 & 3.43 & 0.0006 \\
\hline FAM & $\mathrm{CON}$ & NO & NFAM & SRV & YES & -0.04539 & 0.1362 & 508 & -0.33 & 0.7390 \\
\hline FAM & $\mathrm{CON}$ & NO & NFAM & TRD & $\mathrm{NO}$ & -0.04079 & 0.07347 & 519 & -0.56 & 0.5790 \\
\hline FAM & $\mathrm{CON}$ & $\mathrm{NO}$ & NFAM & TRD & YES & -0.3853 & 0.066 & 578 & -5.77 & $<.0001$ \\
\hline FAM & $\mathrm{CON}$ & YES & NFAM & $\mathrm{CON}$ & NO & 0.7182 & 0.2322 & 32.4 & 3.09 & 0.0041 \\
\hline FAM & $\mathrm{CON}$ & YES & NFAM & $\mathrm{CON}$ & YES & 0.4233 & 0.2619 & 49.5 & 1.62 & 0.1124 \\
\hline FAM & $\mathrm{CON}$ & YES & NFAM & MFG & $\mathrm{NO}$ & 0.9889 & 0.2389 & 36.3 & 4.14 & 0.0002 \\
\hline FAM & $\mathrm{CON}$ & YES & NFAM & MFG & YES & 0.3378 & 0.2481 & 40.2 & 1.36 & 0.1808 \\
\hline FAM & $\mathrm{CON}$ & YES & NFAM & SRV & $\mathrm{NO}$ & 0.7468 & 0.2259 & 29.2 & 3.31 & 0.0025 \\
\hline FAM & $\mathrm{CON}$ & YES & NFAM & SRV & YES & 0.4051 & 0.2546 & 44.5 & 1.59 & 0.1186 \\
\hline FAM & $\mathrm{CON}$ & YES & NFAM & TRD & $\mathrm{NO}$ & 0.4097 & 0.2222 & 27.3 & 1.84 & 0.0760 \\
\hline FAM & $\mathrm{CON}$ & YES & NFAM & TRD & YES & 0.06517 & 0.2261 & 27.8 & 0.29 & 0.7753 \\
\hline
\end{tabular}


who export outperform all other nonfamily businesses who export in all sectors except those who also trade. Still, in the latter case, there is no statistical difference between the two.

\section{Summary and Conclusions}

The message from the preceding results is that industry and institutions matter. In terms of preponderance of evidence by sector, as measured by the statistically significant cases in which family businesses outperform nonfamily businesses; family businesses are strongest in trading, followed by construction as a far second. Family businesses are weakest in manufacturing and services. More importantly, only in trading did family businesses outperform nonfamily exporting businesses in other sectors.

There are three distinguishing characteristics of the trading sector in Dubai that may explain the superior performance of family businesses in that sector relative to other sectors. The first is institutional. UAE families in

Table 5. Comparative performance of family businesses in manufacturing.

\begin{tabular}{|c|c|c|c|c|c|c|c|c|c|c|}
\hline $\mathrm{B}$ & I & $E$ & $\mathrm{~B}$ & I & $\mathrm{E}$ & Estimate & Stan-dard Error & $\mathrm{DF}$ & t Value & $\operatorname{Pr}>|t|$ \\
\hline FAM & MFG & $\mathrm{NO}$ & NFAM & $\mathrm{CON}$ & $\mathrm{NO}$ & 0.1152 & 0.1032 & 255 & 1.12 & 0.2654 \\
\hline FAM & MFG & NO & NFAM & $\mathrm{CON}$ & YES & -0.1798 & 0.1506 & 417 & -1.19 & 0.2331 \\
\hline FAM & MFG & NO & NFAM & MFG & NO & 0.3858 & 0.1175 & 351 & 3.28 & 0.0011 \\
\hline FAM & MFG & NO & NFAM & MFG & YES & -0.2652 & 0.1249 & 435 & -2.12 & 0.0343 \\
\hline FAM & MFG & NO & NFAM & SRV & NO & 0.1438 & 0.08782 & 157 & 1.64 & 0.1036 \\
\hline FAM & MFG & NO & NFAM & SRV & YES & -0.1979 & 0.1373 & 336 & -1.44 & 0.1504 \\
\hline FAM & MFG & NO & NFAM & TRD & NO & -0.1933 & 0.07806 & 113 & -2.48 & 0.0147 \\
\hline FAM & MFG & NO & NFAM & TRD & YES & -0.5379 & 0.07202 & 126 & -7.47 & 0.0001 \\
\hline FAM & MFG & YES & NFAM & $\mathrm{CON}$ & NO & 0.3059 & 0.1528 & 251 & 2.00 & 0.0464 \\
\hline FAM & MFG & YES & NFAM & $\mathrm{CON}$ & YES & 0.01097 & 0.1950 & 421 & 0.06 & 0.9552 \\
\hline FAM & MFG & YES & NFAM & MFG & NO & 0.5766 & 0.1629 & 311 & 3.54 & 0.0005 \\
\hline FAM & MFG & YES & NFAM & MFG & YES & -0.07450 & 0.1760 & 368 & -0.42 & 0.6723 \\
\hline FAM & MFG & YES & NFAM & SRV & NO & 0.3345 & 0.1433 & 198 & 2.33 & 0.0206 \\
\hline FAM & MFG & YES & NFAM & SRV & YES & -0.00721 & 0.1852 & 360 & -0.04 & 0.9690 \\
\hline FAM & MFG & YES & NFAM & TRD & NO & -0.00261 & 0.1370 & 167 & -0.02 & 0.9848 \\
\hline FAM & MFG & YES & NFAM & TRD & YES & -0.3472 & 0.1432 & 175 & -2.42 & 0.0164 \\
\hline
\end{tabular}

Table 6. Comparative performance of family businesses in services.

\begin{tabular}{|c|c|c|c|c|c|c|c|c|c|c|}
\hline $\mathrm{B}$ & $\mathrm{I}$ & $\mathrm{E}$ & $\mathrm{B}$ & $\mathrm{I}$ & $\mathrm{E}$ & Estimate & Standard Error & DF & t Value & $\operatorname{Pr}>|t|$ \\
\hline FAM & SRV & $\mathrm{NO}$ & NFAM & $\mathrm{CON}$ & $\mathrm{NO}$ & -0.04689 & 0.06359 & 2694 & -0.74 & 0.4610 \\
\hline FAM & SRV & NO & NFAM & $\mathrm{CON}$ & YES & -0.3418 & 0.1269 & 394 & -2.69 & 0.0074 \\
\hline FAM & SRV & NO & NFAM & MFG & NO & 0.2238 & 0.08432 & 1010 & 2.65 & 0.0081 \\
\hline FAM & SRV & NO & NFAM & SRV & NO & -0.01828 & 0.02726 & 3481 & -0.67 & 0.5026 \\
\hline FAM & SRV & NO & NFAM & SRV & YES & -0.3600 & 0.1093 & 294 & -3.29 & 0.0011 \\
\hline FAM & SRV & YES & NFAM & $\mathrm{CON}$ & NO & 0.4823 & 0.1831 & 124 & 2.63 & 0.0095 \\
\hline FAM & SRV & YES & NFAM & $\mathrm{CON}$ & YES & 0.1874 & 0.2197 & 215 & 0.85 & 0.3946 \\
\hline FAM & SRV & YES & NFAM & MFG & NO & 0.7530 & 0.1913 & 145 & 3.94 & 0.0001 \\
\hline FAM & SRV & YES & NFAM & MFG & YES & 0.1019 & 0.2028 & 169 & 0.50 & 0.6159 \\
\hline FAM & SRV & YES & NFAM & SRV & NO & 0.5109 & 0.1738 & 102 & 2.94 & 0.0041 \\
\hline FAM & SRV & YES & NFAM & SRV & YES & 0.1692 & 0.2100 & 183 & 0.81 & 0.4213 \\
\hline FAM & SRV & YES & NFAM & TRD & NO & 0.1738 & 0.1704 & 94.2 & 1.02 & 0.3104 \\
\hline FAM & SRV & YES & NFAM & TRD & YES & -0.1707 & 0.1756 & 97.5 & -0.97 & 0.3333 \\
\hline
\end{tabular}

Table 7. Comparative performance of family businesses in trading.

\begin{tabular}{|c|c|c|c|c|c|c|c|c|c|c|}
\hline $\mathrm{B}$ & $\mathrm{I}$ & $\mathrm{E}$ & $\mathrm{B}$ & I & $\mathrm{E}$ & Estimate & Standard Error & DF & t Value & $\operatorname{Pr}>|t|$ \\
\hline FAM & TRD & $\mathrm{NO}$ & NFAM & $\mathrm{CON}$ & $\mathrm{NO}$ & 0.2043 & 0.05755 & 2193 & 3.55 & 0.0004 \\
\hline FAM & TRD & NO & NFAM & $\mathrm{CON}$ & YES & -0.09064 & 0.1237 & 363 & -0.73 & 0.4640 \\
\hline FAM & TRD & NO & NFAM & MFG & NO & 0.4749 & 0.08124 & 918 & 5.85 & $<.0001$ \\
\hline FAM & TRD & NO & NFAM & MFG & YES & -0.1761 & 0.09112 & 728 & -1.93 & 0.0537 \\
\hline FAM & TRD & NO & NFAM & SRV & NO & 0.2329 & 0.02861 & 3591 & 8.14 & $<.0001$ \\
\hline FAM & TRD & NO & NFAM & SRV & YES & -0.1088 & 0.1091 & 291 & -1.00 & 0.3192 \\
\hline FAM & TRD & YES & NFAM & $\mathrm{CON}$ & NO & 0.6178 & 0.07954 & 2319 & 7.77 & $<.0001$ \\
\hline FAM & TRD & YES & NFAM & $\mathrm{CON}$ & YES & 0.3229 & 0.1448 & 425 & 2.23 & 0.0263 \\
\hline FAM & TRD & YES & NFAM & MFG & NO & 0.8884 & 0.09806 & 1169 & 9.06 & $<.0001$ \\
\hline FAM & TRD & YES & NFAM & MFG & YES & 0.2374 & 0.1182 & 901 & 2.01 & 0.0449 \\
\hline FAM & TRD & YES & NFAM & SRV & NO & 0.6464 & 0.06198 & 2177 & 10.43 & $<.0001$ \\
\hline FAM & TRD & YES & NFAM & SRV & YES & 0.3047 & 0.1326 & 352 & 2.30 & 0.0221 \\
\hline FAM & TRD & YES & NFAM & TRD & NO & 0.3093 & 0.04132 & 1015 & 7.48 & $<.0001$ \\
\hline FAM & TRD & YES & NFAM & TRD & YES & -0.03527 & 0.05844 & 1296 & -0.60 & 0.5463 \\
\hline
\end{tabular}


the trading sector have historically been granted exclusive commercial licenses by the government. To the extent that such licenses might lead to monopoly power, the implications for performance are clear. Second, because successful trading has historically been and still is tied to strong family networks, the stronger performance of family businesses is a manifestation of the strength of those networks. The strength of family network also helps explain why nonfamily businesses who export are on par with family businesses who also export. Nonfamily businesses in the trading sector also rely on family and nonfamily networks in native countries of the owners of nonfamily businesses. Third, trading has the least technological requirement, thus exposing UAE traders to less competition from the rest of the sectors, where the technological requirements are relatively higher.

The policy implication is that in order to bring Dubai family businesses on par with nonfamily businesses in the other more technologically demanding sectors, a technology adoption agenda needs to be targeted towards family businesses in those sectors.

\section{References}

[1] P. Jaskiewicz and S. Klein. "Family Influence and Performance-Theoretical Concepts and Empirical Results," Paper Presented at the FERC Conference, Portland, Oregon, 2005.

[2] W. G. Dyer Jr., "Examining the 'Family Effect' on Firm Performance," Family Business Review, Vol. 19, No. 4, 2006, pp. 253-273.

doi:10.1111/j.1741-6248.2006.00074.x

[3] B. Kotey, "Are Performance Differences between Family and Non-family SMEs Uniform across All Firm Sizes?" International Journal of Entrepreneurial Behaviour \& Research, Vol. 11, No. 6, 2005, pp. 394-421. doi:10.1108/13552550510625168

[4] R. Anderson and D. Reeb, "Founding-Family Ownership and Firm Performance: Evidence from the S\&P 500," Journal of Finance, Vol. 58, No. 3, 2003, pp. 1301-1328. doi:10.1111/1540-6261.00567

[5] B. Lauterbach and A. Vaninsky, "Ownership Structure and Firm Performance: Evidence from Israel," Journal of Management and Governance, Vol. 3, No. 2, 1999, pp. 189-201. doi:10.1023/A:1009990008724

[6] P. Westhead and M. Cowling, "Performance Contrasts Between Family and Non-family Unquoted Companies in the UK," International Journal of Entrepreneurial Behaviour \& Research, Vol. 3, No. 1, 1997, pp. 30-52. doi:10.1108/13552559710170892

[7] C. Daily and M. Dollinger, "An Empirical Examination of Ownership Structure in Family and Professionally Managed Firms," Family Business Review, Vol. 5, No. 2, 1992, pp. 117-136. doi:10.1111/j.1741-6248.1992.00117.x
[8] J. J. Heckman, "Sample Selection Bias as Specification Error," Econometrica, Vol. 47, No. 1, 1979, pp. 153-161. doi:10.2307/1912352

[9] J. Davis, E. Pitts and K. Cormier, "Challenges Facing the Family Companies in the Gulf Region," SAMA (2006G): Saudi Arabian Monetary Agency, Forty-Second Annual Report, Research and Statistics Department, 1997.

[10] A. Shleifer and R. Vishny, "Management Entrenchment: the Case of Manager-Specific Investment," Journal of Financial Economics, Vol. 25, No. 1, 1997, pp. 123-139. doi:10.1016/0304-405X(89)90099-8

[11] M. Jensen and W. Meckling, "Theory of the Firm: Managerial Behavior, Agency Costs and Ownership Structure," Journal of Financial Economics, Vol. 3, 1976, pp. 305-360. doi:10.1016/0304-405X(76)90026-X

[12] C. Romano, G. Tanewski and K. Smyrnios, "Capital Structure Decision Making: A Model for Family Business," Journal of Business Venturing, Vol. 16, No. 3, 2000, pp. 285-310. doi:10.1016/S0883-9026(99)00053-1

[13] M. Mustakallio, "Contractual and Relational Governance in Family Firms: Effects on Strategic Decision-Making Quality and Firm Performance," Helsinki University of Technology, Doctoral Dissertations 2002/2, 2002.

[14] R. Morck, D. Wolfenzon and B. Yeung, "Corporate Governance, Economic Entrenchment, and Growth," Journal of Economic Literature, Vol. XLIII, 2005, pp. 655-720. doi: $10.1257 / 002205105774431252$

[15] N. M. Young, M. W. Peng, D. Ahlstrom, G. D. Bruton, and Y. Jiang, "Corporate Governance in Emerging Economies: A Review of the Principal-Principal Perspective," Journal of Management Studies, Vol. 45, No. 1, 2008, pp. 196-220. doi:10.1111/j.1467-6486.2007.00752.x

[16] D. C. Mueller, "Corporate Governance and Economic Growth," International Review of Applied Economics, Vol. 20, No. 5, 2006, pp. 623-643. doi:10.1080/02692170601005598

[17] R. Morck and B. Yeung, "Special Issues Relating to Corporate Governance and Family Control," Global Corporate Governance Forum, Discussion Paper No. 1, Washington DC, 2004.

[18] R. La Porta, F. Lopez-de-Silanes, A. Shleifer and R. Vishny, "Investor Protection and Corporate Governance," Journal of Financial Economics, Vol. 58, 2000, pp. 3-27. doi:10.1016/S0304-405X(00)00065-9

[19] H. Demsetz and K. Lehn, "The Structure of Ownership: Causes and Consequences," Journal of Political Economics, Vol. 93, No. 6, 1985, pp. 1155-1177.

[20] M. Jagannathan, "Internal Control Mechanisms and Forced CEO Turnover: An Empirical Investigation,” PhD Dissertation, Virginia Polytechnic Institute and State University, 1996.

[21] C. Erdener and D. Shapiro, "The International of Chinese Family Enterprises and Dunning's Eclectic MNE paradigm," Management and Organization Review, Vol. 1, No. 3, 2005, pp. 411-436. 


\section{doi:10.1111/j.1740-8784.2005.00021.x}

[22] W. Schulze and R. Dino, "The Impact of Distribution of Ownership on the Use of Financial Leverage in the Family Firms," Proceedings of the 12th Annual Conference of the United States Association for Small Business and Entrepreneurship, 1998.

[23] T. Zellweger, "Risk, Return and Value in the Family Firm," Dissertation No. 3188, The University of Saint Gallen, 2006.

[24] D. McConaughy C. Matthews and A. Fialko, "Founding Family Controlled Firms: Efficiency, Risk and Value," Journal of Small Business Management, Vol. 39, No. 1, 2001, pp. 31-49. doi:10.1111/0447-2778.00004

[25] A. Jorissen, E. Laveren, R. Martens and A. Reheul, "Differences between Family and Non-family Firms 'Real' versus 'Sample-Based' Differences," Family Firm Institute, Vol. 18, No. 13, 2005,

[26] J. Lee, "Family Firm Performance: Further Evidence," Family Business Review, Vol. 19, No. 2, 2006, pp. 103114. doi:10.1111/j.1741-6248.2006.00060.x

[27] A. Suehiro, "Family Business Gone Wrong? Ownership
Patterns and Corporate Performance in Thailand," Asian Development Bank Institute, Working Paper 19, ABD Institute, Tokyo, 2001.

[28] J. H. Chua, J. J. Christman and P. Sharma, "Defining the Family Business by Behaviour," Entrepreneurship Theory and Practice, Vol. 23, No. 4, 1999, pp. 19-38.

[29] K. Gersick, J. Davis, McCollom, M. Hampton and I. Lansberg, "Generation to Generation: Life Cycles of the Family Business," Harvard Business School Press, Harvard, 1997.

[30] B. Rettab, "Dubai Family Enterprises: Definition, Structure and Performance", In: V. Gupta, et al., Eds., A Compendium on the Family Business Models Around the World, ICFAI University Press, Hyderabad, 2008.

[31] S. Chatterjee and B. Price, "Regression Analysis by Example," 2nd Edition, Wiley \& Sons, New York, 1991.

[32] R. C. Little, G. A. Milliken, W. W. Stroup, R. D. Wolfinger and O. Schabenberger, "SAS for Mixed Model, Second Editions," SAS Institue Inc., North Carolina, 2006 . 